\title{
Pengungkapan informasi pada website: studi tentang akuntabilitas pendidikan pada perguruan tinggi di Indonesia
}

\author{
Indrawati Yuhertiana \\ UPN "Veteran" Jawa Timur \\ Jl.Raya Rungkut Madya Gununganyar Surabaya \\ Email:yuhertiana@yahoo.com
}

\begin{abstract}
This study aims to evaluate the forms of disclosure of the information presented on the college website. Qualitative research was conducted using document analysis at 10 universities ranked highest according to the version webometrics in 2008. The results showed that the general form of the disclosures made mostly still is the promotion to attract new students by providing excellent products universities, namely education, research and dedication to community. In the case of disclosure of information relating to the management of the majority of new college presents information related to strategic planning such as vision and mission, as well as organizational structure. In contrast to the best universities of the world, there is only a college that informs its financial statements. Some still express his policies are even some that did not inform the finances at all.
\end{abstract}

Keywords: accountability, financial disclosure, good university governance, website

\section{Pendahuluan}

Pendidikan adalah sangat penting bagi peradaban manusia, untuk meningkatkan kualitas manusia sehingga dapat menguasai dan mengembangkan ilmu pengetahuan. Sebuah negara maju pasti didukung oleh kualitas warga negaranya yang memiliki pendidikan tinggi. Namun demikian tidaklah mudah melakukan pengelolaan pendidikan. Dibutuhkan sarana prasarana baik fisik maupun non fisik untuk mendukung proses pembelajaran yang baik. Misalnya murid atau mahasiswa akan dapat belajar dengan baik dan dapat menyerap pelajaran jika belajar di ruang kelas yang nyaman, tenang, memiliki fasilitas pembelajaran yang modern seperti internet, buku-buku, publikasi ilmiah dan lain-lain. Dosennya pun adalah dosen berkualitas karena memiliki kompetensi yang dibangun dengan gelar akademik yang tinggi dan mampu melakukan dan menghasilkan penelitian yang baik. Ini semua tak luput dari pengelolaan operasional yang kesemuanya membutuhkan dana. Pengelolaan pendidikan secara profesional menjadi mutlak.

Di sisi lain pendidikan menjadi hak bagi setiap manusia. Banyak negara menjadikan pendidikan sebagai prioritas pembangunannya.Di Indonesia, Amandemen UUD 45 dan Pasal 49 UU Sisdiknas menegaskan bahwa dana pendidikan selain gaji pendidik dan biaya pendidikan kedinasan dialokasikan minimal $20 \%$ dari APBN pada sektor pendidikan dan minimal $20 \%$ dari APBD. Realitanya jumlah ini ternyata masih lebih kecil dibandingkan negar Asia lainnya jika dilihat dari persentase terhadap PDB-nya, (Lihat tabel 1).

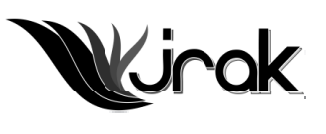

Jurnal Reviu Akuntansi dan Keuangan ISSN: $2088-0685$ Vol.1 No. 1, April 2011 


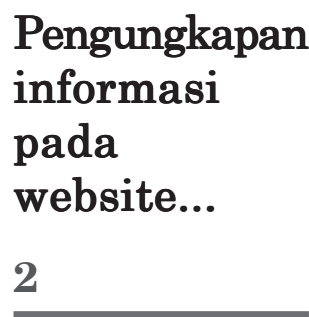

Tabel 1

Persentase Anggaran Pendidikan terhadap PDB

\begin{tabular}{llc}
\hline NO & NEGARA & PERSENTASE ANGGARAN \\
\hline 1 & Indonesia & 1,4 \\
2 & Nigeria & 2,4 \\
3 & Vietnam & 2,8 \\
4 & Sri Lanka & 3,4 \\
5 & Filipina & 3,4 \\
6 & Brunei & 4,4 \\
7 & Thailand & 5,0 \\
8 & India & 5,1 \\
9 & Malaysia & 5,2 \\
10 & Korea Selatan & 5,3 \\
11 & Jepang & 7,3 \\
\hline
\end{tabular}

Sumber: World Development Indicators, 2003

Namun di sisi lain, keuangan negara yang terbatas seringkali tidak cukup mampu menyediakan sarana prasarana yang berkualitas karena terbatasnya dana yang dimiliki. Disinilah kemudian dibutuhkan peran masyarakat untuk membantu negara menyelenggarakan penyelenggaraan pendidikan sehingga banyak bermunculan lembaga pendidikan yang dikelola oleh swasta.

Pengelolaan pendidikan dituntut dilakukan secara profesional. Isu tata kelola yang baik atau good governance tak luput terjadi pada organisasi kependidikan, khususnya pendidikan tinggi. Good university governance tampaknya tidak lagi menjadi sebuah isu atau wacana tapi perlu segera diimplementasikan apalagi dengan munculnya UU tentang Badan Hukum Pendidikan.

Adapun pilar-pilar good governance antara lain adalah akuntabilitas dan transparansi. Peran akuntansi akan sangat besar mendukung kedua pilar tersebut. Oleh karena itu akuntansi pendidikan mulai berkembang sejalan dengan tuntutan untuk mengakomodir kebutuhan tersebut. Disinilah akuntansi pendidikan sebagai bagian dari akuntansi sektor publik berkembang dengan berbagai penelitiannya. Akuntansi pendidikan, bagian dari akuntansi sektor publik-nirlaba. Kegiatan pendidikan merupakan kegiatan yang tidak bertujuan mencari keuntungan, sehingga apabila timbul keuntungan atau sisa hasil usaha dari kegiatan pendidikan yang nirlaba, baik secara langsung atau tidak langsung, maka seluruh keuntungan atau sisa hasil usaha tersebut wajib digunakan kembali untuk menjalankan kegiatan pendidikan yang nirlaba tersebut (Gunawan, tanpa tahun)

Siapa atau apa yang dimaksud dengan 'penyelenggara'Ketika UU Sisdiknas diundangkan 8 Juli 2003, masih berlaku PP No. 60 /1999 tentang Pendidikan Tinggi, sampai sekarang Pasal 119 PP No.60/1999 menyatakan: Pendirian perguruan tinggi yang diselenggarakan oleh masyarakat selain memenuhi ketentuan sebagaimana diatur dalam PP ini harus pula memenuhi persyaratan bahwa penyelenggaranya berbentuk yayasan atau badan yang bersifat sosial.

Penelitian ini bertujuan untuk menggali sejauh mana akuntabilitas dan transparansi organisasi kependidikan khususnya perguruan tinggi. Hal ini dikarenakan Selain itu, transparansi dan akuntabilitas harus terus dilakukan. Stakeholders dapat dengan mudah mengakses informasi-informasi mengenai anggaran dan keuangan institusi PTN. Hal ini akan memudahkan semua pihak untuk memantau tingkat efektivitas dan efisiensi program yang dijalankan serta efektifitas dan efisiensi anggaran. Stakeholders juga memiliki akses dan kesempatan untuk memberikan masukan atau evaluasi selama program berjalan.

Penelitian ini juga menjadi penting karena kurangnya komunikasi dan informasi, pada realita muncul beberapa fenomena yang semuanya bermuara pada pertanyaan tentang implementasi good governance. Pertama, beberapa aksi demonstrasi mahasiswa di perguruan tinggi seperti demo mahasiswa Padang, mahasiswa Universitas Indonesia, Universitas Padjajaran yang intinya adalah menuntut transparansi pengelolaan dana dan pertanyaan tentang mahalnya SPP. Kedua, hasil audit BPK, bahwa dari 82 Perguruan Tinggi Negeri di Indonesia, hanya dua yang wajar tanpa pengecualian yaitu UGM dan Unair. 
Dengan demikian penelitian eksplorasi ini berfokus untuk menjawab pertanyaan penelitian:

- Apakah perguruan tinggi di Indonesia yang termasuk dalam sepuluh perguruan tinggi terbaik di Indonesia sudah mengungkapkan informasi keuangannya pada pada website universitas sebagai wujud akuntabilitas dan transparasi dalam kerangka good university governance?

- Bagaimana bentuk informasi dan laporan keuangan universitas?

\section{Metode}

Penelitian ini adalah survey awal yang bersifat eksplorasi untuk menggali sejauhmana penerapan good university governance. Dari beberapa pilar good governance antara lain adalah transparansi dan akuntabilitas. Salah satu media yang dapat digunakan untuk menilai ini adalah website (Abhiseka, A. 2003 ).

Penelitian ini mencoba mengungkapkan informasi yang disajikan pada website perguruan tinggi, dengan konsentrasi utama pencarian pada informasi tentang laporan keuangan. Jenis data adalah data sekunder yang diperoleh dengan mengamati secara teliti berbagai informasi terutama terkait dengan informasi keuangan yang disajikan pada website perguruan tinggi.

Penelitian ini mengambil sampel sepuluh universitas yang menurut webometrics berada pada 10 peringkat tertinggi tahun 2008. Alasan pemilihan adalah karena webometrics merupakan badan pemeringkat yang lebih mengutamakan pada konten website sesuai dengan tujuan penelitian ini untuk mengeksplorasi akuntabilitas publik dengan media internet. Kesepuluh universitas tersebut adalah:

- Universitas Gadjah Mada (UGM)

- Institut Teknologi Bandung (ITB)

- Universitas Indonesia (UI)

- Universitas Kristen Petra (PETRA)

- Universitas Gunadarma (UG)

- Universitas Negeri Malang (UM)

- Institut Teknologi Sepuluh Nopember (ITS)

- Universitas Sebelas Maret (UNS)

- Universitas Airlangga (UNAIR)

- Universitas Brawijaya (UNBRA)

\section{Teknik Analisis.}

Teknik analisis yang dilakukan adalah analisis dokumen. Analisis Dokumen (Document Analysis) merupakan salah satu teknik pengolahan citra digital untuk memperoleh informasi secara cepat dan otomatis melalui media cetak. Tahapan analisis ini adalah:

- Mencari informasi perguruan tinggi terbaik menurut webometrics

- Memasuki website 10 perguruan tinggi tersebut dengan mengobservasi kemudahan akses, kemudahan penggunaan (ease of use), kenyamanan berselancar pada website tersebut.

- Mengamati informasi yang ditampilkan di website, mengumpulkan dan mentabulasikan informasi serta menelaah informasi yang disajikan.

- Menginterpretasikan informasi yang disajikan dengan menghubungkannya pada konten good university governance, yang berfokus pada akuntabilitas dan transparansi keuangan. 


\section{Pengungkapan informasi pada website...}

4

Tabel 1

Informasi Renstra pada Website

Perguruan Tinggi

Keterangan:

1: ada informasi

0 : tidak ada informasi

\section{Pembahasan}

\section{Penyajian informasi pada website Perguruan Tinggi di Indonesia.}

Perkembangan teknologi internet telah memaksa berbagai institusi melakukan perubahan mindset, terutama karena kemudahan mengakses, cepat dan murah, internet menjadi sebuah pilihan yang mau tidak mau harus menjadi pilihan saat ini. Calon mahasiswa akan dapat dengan mudah memilih untuk menentukan perguruan tinggi yang disukainya dengan membuka website universitas yang dipilihnya. Apakah ada program studi yang dimilikinya, berkualitas dan sesuai dengan kemampuan ekonominya. Dengan kata lain, saat ini website tidak hanya sekedar sebagai media untuk menyampaikan image, profile sebuah institusi tetapi juga menjadi alat promosi. Bahkan saat ini, dikenal webometrics, yang melakukan pemeringkatan perguruan tinggi berdasarkan aksesability-nya di internet.

Eksplorasi terhadap sepuluh website perguruan tinggi terbaik di Indonesia menurut versi webometrics (dari 270 website perguruan tinggi Indonesia yang terdaftar) tersebut mempertegas fungsi website sebagai sarana promosi. Seluruh tampilan website berisi informasi yang menyajikan informasi tentang tiga hal yaitu pendidikan, penelitian dan pengabdian pada masyarakat sesuai dengan tri dharma perguruan tinggi. Pendidikan meliputi program studi yang ditawarkan, kurikulum, fasilitas, e-learning. Penelitian menyajikan informasi hasil dan prestasi penelitian. Demikian juga pengabdian masyarakat berisi informasi tentang kegiatan yang berhubungan dengan kerjasama universitas dengan berbagai pihak.

Terkait dengan Good University Governance, penelitian ini berusaha mencari informasi tentang visi, misi, tujuan dan sasaran organisasi. Informasi ini penting disajikan bagi stakeholder karena merupakan bagian dalam rencana strategis perusahaan. Penting juga sebagai bahan evaluasi apakah kebijakan yang dilaksanakan oleh manajemen perguruan tinggi telah mengacu untuk mewujudkan visi-misi tersebut.

\begin{tabular}{clcccc}
\hline NO & PERGURUAN TINGGI & VISI & MISI & TUJUAN & SASARAN \\
\hline 1 & UGM & 1 & 1 & 1 & 1 \\
2 & ITB & 1 & 1 & 1 & 0 \\
3 & UI & 1 & 1 & 1 & 0 \\
4 & UK PETRA & 0 & 0 & 0 & 0 \\
5 & Univ. Gunadarma & 1 & 1 & 1 & 0 \\
6 & Univ. Negeri Malang & 1 & 1 & 1 & 0 \\
7 & ITS & 1 & 1 & 1 & 0 \\
8 & UNS & 1 & 1 & 1 & 0 \\
9 & UNAIR & 1 & 1 & 1 & 0 \\
10 & UNBRAW & 1 & 1 & 1 & 0 \\
\hline
\end{tabular}

Sumber: Data diolah

Tidak semua perguruan tinggi menganggap perlu menyampaikan visi, misi, tujuan dan sasarannya. Tidak berarti perguruan tinggi yang tidak menyajikan informasi ini tidak memiliki visi, misi, dipastikan seluruh perguruan tinggi pasti sudah memiliki visi, misi dan tujuan karena merupakan bagian persyaratan akreditasi.

UGM adalah yang paling lengkap menyajikan informasi tentang renstranya, termasuk sasaran yang ingin diwujudkannya. Hasil analisis konten terhadap informasi tentang renstra perguruan tinggi ditemukan dua perguruan tinggi, yaitu UGM dan UM telah bersepakat untuk menerapkan good university governance. Seperti misi ketiga dari UGM yang menyatakan: Menuntaskan transisi UGM menjadi universitas yang mandiri dan mempunyai tata kelola yang baik (Good University Governance. Dan kemudian mengejawantahkan dalam tujuannya: Menjadi Universitas yang mandiri dan bertata kelola baik (Good University Governance). Sasaran terkait dengan akuntabilitas keuangan. 1)Tersusunnya laporan keuangan sesuai standar akuntansi yang berlaku bagi universitas yang mandiri, 2) Tercapainya good governance dalam sistem manajemen. 
UM juga telah berkomitmen melaksanakan good governance dalam misinya yaitu Membangun organisasi yang sehat dalam rangka penguatan tata kelola, transparansi, dan pencitraan publik menuju per-guruan tinggi yang otonom. Namun UM tidak mengejawantahkan lebih lanjut dalam tujuan dan sasarannya.

Fakta ini menunjukkan bahwa perguruan tinggi di Indonesia beberapa perguruan tinggi menyadari pentingnya implementasi konsep good governance dilakukan secara sungguh-sungguh dalam visi misi mereka.

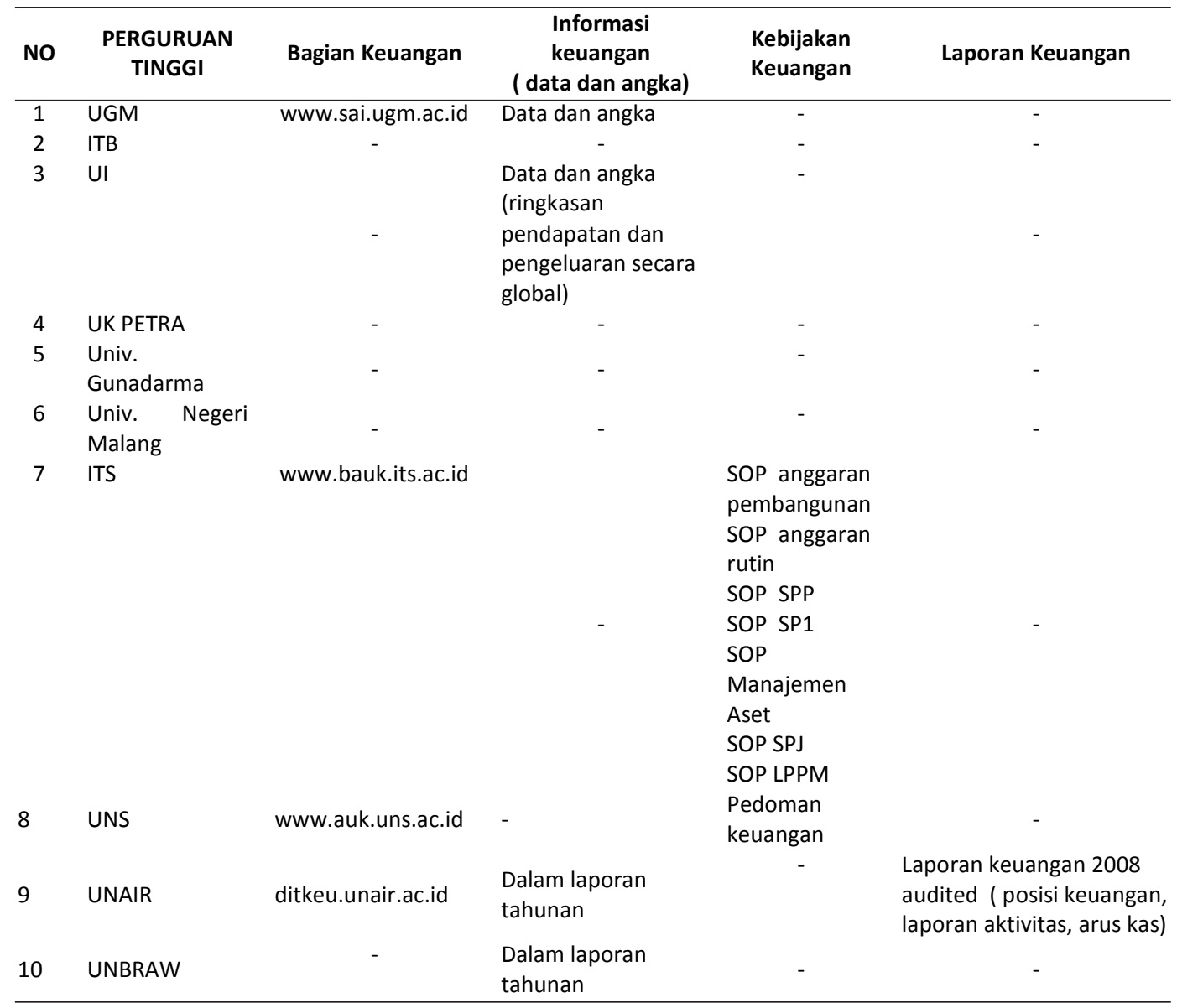

\section{Bentuk penyajian informasi keuangan di Website Perguruan Tinggi}

Adalah lebih mudah mencari laporan keuangan universitas luar negeri daripada mencari dalam negeri. Penelusuran laporan keuangan organisasi pendidikan dengan mengetikkan kata kunci dalam bahasa Indonesia lebih sulit dilakukan. Namun ketika diketik "university financial report" ada banyak sekali laporan keuangan perguruan tinggi yang muncul.

Penelusuran terhadap universitas terbaik peringkat webometrics, Harvard university, Cornel University dan Berkeley University diperoleh informasi yang sangat lengkap tentang laporan keuangan. Laporan keuangan diproduksi oleh kantor atau departem controller. Laporan keuangan biasanya merupakan bagian dari laporan tahunan universitas.

Jenis laporan keuangan di Amerika Serikat, terdiri dari:

1. Management's Discussion and Analysis. MDA bertujuan untuk membantu pembaca atau stakeholder lebih mudah memahami laporan keuangan, melalui analisis keuangan yang disiapkan oleh pihak manajemen.

2. Financial Statements:

- Statements of Net Assets

- Statements of Revenues, Expenses and Changes in Net Assets

- Statements of Cash Flows

- Notes to Financial Statements 
Pengungkapan informasi pada website...
Di Indonesia belum banyak perguruan tinggi yang menginformasikan laporan keuangannya. Hasil penelusuran di internet menemukan hanya ada dua perguruan tinggi yaitu Unair dan UPI yang menyajikan laporan keuangannya berupa laporan posisi keuangan, laporan aktivitas dan laporan arus kas yang telah diaudit oleh akuntan publik.

Nampaknya hal ini sejalan dengan perkembangan implementasi good university governance yang baru dimulai di Indonesia. Penataan pengelolaan pendidikan tinggi di Indonesia saat ini mengalami perkembangan yang cukup signifikan sejalan dengan tuntutan masyarakat akan otonomi perguruan tinggi agar lebih mudah berinovasi melakukan peningkatan kualitas pembelajaran. Dimulai pada tahun 1989 dengan lahirnya UU tentang Sistem Pendidikan Nasional. Menurut Muttaqin, 2009, setidaknya ada tiga model pengelolaan perguruan tinggi negeri yang berkembang saat ini. Pertama pola PTN konvensional yang selama ini dilakukan PTN dengan mengacu pada UU No 2/1989 tentang Sistem Pendidikan Nasional dan PP No 60/1999 tentang Pendidikan Tinggi. Kedua, pola BHMN dengan mengacu pada UU No 2/1989 tentang Sistem Pendidikan Nasional, PP No 61/1999 tentang Perguruan Tinggi Badan Hukum, dan PP 152-155/2000 untuk empat PTN, yaitu Universitas Indonesia (UI), Institut Teknologi Bandung (ITB), Universitas Gadjah Mada (UGM), dan Institut Pertanian Bogor (IPB). Pada tahap selanjutnya Universitas Sumatera Utara (USU), Universitas Pendidikan Indonesia (UPI), dan Universitas Airlangga (Unair) menyusul menjadi PT BHMN. Ketiga, pola badan layanan umum yang bersandar pada UU No 2/1989 dan UU No 20/2003 tentang Sistem Pendidikan Nasional dan UU No 1/2004 tentang Perbendaharaan Negara serta PP No 60/1999 dan PP No 23/2005 tentang Pengelolaan Keuangan BLU. Universitas Diponegoro (Undip) dan Universitas Padjadjaran (Unpad) adalah penganut model BLU ini. Adapun pada tahun 2009 terbit UU no 9 tentang Badan Hukum Pendidikan. Kelahiran UU BHP sejalan dengan perkembangan masyarakat yang semakin menuntut layanan yang lebih baik dan responsif dengan pengelolaan perguruan tinggi dituntut untuk meningkatkan kualitas layanannya. Hal itu semakin dirasakan dengan semakin terbukanya persaingan dalam penyediaan jasa pendidikan tinggi.

\section{Transparansi Perguruan Tinggi}

Salah satu prinsip pengelolaan badan hukum pendidikan dalam UU BHP adalah prinsip transparansi. Maksudnya adalah keterbukaan dan kemampuan menyajikan informasi yang relevan secara tepat waktu sesuai dengan ketentuan peraturan perundang-undangan dan standar pelaporan yang berlaku kepada pemangku kepentingan. Implementasi prinsip transparansi ini perlu komitmen pimpinan PT serta persiapan yang matang. Banyak tantangan yang akan dihadapi dalam implementasinya.

Laporan tahunan adalah sebuah kewajiban yang perlu disampaikan pada publik. Salah satu aspek transparansi dapat dilihat pada Bagian VII tentang Akuntabilitas dan Pengawasan UU BHP. Pengawasan badan hukum pendidikan dilakukan melalui sistem pelaporan tahunan. Laporan itu meliputi bidang akademik yaitu kegiatan pendidikan, penelitian, dan pengabdian kepada masyarakat. Sementara itu untuk bidang non-akademik mencakup aspek manajemen dan laporan keuangan.

\section{Akuntansi di era Badan Hukum Pendidikan}

Dalam rangka memenuhi UU no. 9 tahun 2009 tentang BHP dan ketentuan butir-butir akreditasi perguruan tinggi, yang antara lain mensyaratkan tentang penjaminan mutu perguruan tinggi, penyusunan rencana kegiatan dan anggaran berbasis kinerja, serta penyusunan dan publikasi laporan keuangan perguruan tinggi berbasis standar akuntansi keuangan. Berdasarkan UU no 9 tahun 2009, paling lambat pada tahun 2015 poin-poin penting dalam pengelolaan perguruan tinggi berikut harus sudah dilaksanakan: 
Laporan keuangan merupakan bagian dari laporan tahunan badan hukum pendidikan. Laporan tersebut dibuat sesuai dengan standar akuntansi serta diaudit oleh akuntan publik. Laporan keuangan ini harus pula diumumkan kepada publik melalui surat kabar berbahasa Indonesia yang beredar secara nasional dan papan pengumuman.

Laporan keuangan biasanya sangat menarik berbagai pihak pemangku kepentingan. Misalnya para mahasiswa, orang tua, Pemerintah, lembaga swadaya masyarakat dan pers. Pertanyaan-pertanyaan yang selalu muncul, seperti apakah terjadi komersialisasi, bagaimana alokasi dana yang masuk ke PT, dipakai untuk apa saja dan lain-lainnya. Tantangan ini menyiratkan perlunya PT mempersiapkan banyak hal. Misalnya saja sistem keuangan yang valid, policy sumber dan penggunaan dana, kebijakan tarif, penyiapan SDM yang mengelola keuangan PT maupun koordinasi penyiapan informasi untuk unit hubungan pemangku kepentingan.

Akuntabilitas pendidikan turut di atur dalam UU BHP. Pasal 38 berbicara tentang akuntabilitas. Setiap tahunnya pengelola universitas harus menyerahkan laporan keuangan kepada menteri bersama dengan Majelis Wali Amanat. Batas maksimal pembuatan dan penyerahan laporan keuangan kepada menteri adalah lima bulan setelah tutup buku tahunan. Setelah ditandatangani oleh menteri, laporan keuangan selanjutnya bisa diakses oleh masyarakat. Bukan saja mahasiswa atau orang tua mahasiswa yang bisa membaca laporan keuangan tahunan, tapi juga siapa saja yang merasa perlu mengetahui laporan keuangan universitas.

Dari sepuluh universitas yang diteliti hanya satu yang menyajikan laporan keuangannya secara lengkap yaitu Unair (Lampiran). Informasi keuangan tentang pendapatan dan pengeluaran disajikan secara global dalam bentuk ringkasan data dan angka ditampilkan oleh dua perguruan tinggi yaitu UGM dan UI. Laporan tahunan yang menyajikan informasi secara menyeluruh kinerja universitas ditemukan di Universitas Brawijaya dan Unair. Masih ada empat perguruan tinggi yang sama sekali tidak memiliki informasi atau komponen keuangan di websitenya.

Pelaporan akuntansi yang mensyaratkan laporan keuangan harus sesuai dengan standard akuntansi menyebabkan perguruan tinggi harus mampu memahami PSAK 45 yang mengatur akuntansi untuk organisasi nirlaba. Tentu saja ini membutuhkan sosialisasi karena institusi pendidikan tinggi di Indonesia sangat beragam pengelolaannya, pengelolaan baik swasta dibawah yayasan perorangan, maupun yang dimiliki oleh organisasi keagamaan yang pengelolaannya selama ini masih bersifat konvensional dan tertutup. Penerapan UU BHP menuntut adanya perubahan mindset manajemen dan pengurus yayasan karena sesuai tuntutan masyarakat akan akuntabilits publik.

\section{Keterbatasan}

Penelitian ini hanya berdasarkan pada observasi website resmi perguruan tinggi, kesadaran tentang perlunya menginformasikan penting terkait dengan proses pembelajaran masih rendah. Oleh karena itu bukan berarti universitas yang tidak menampilkan informasi keuangan belum memiliki laporan keuangan.

Penelitian ini dilakukan pada tahun 2008 sebelum Undang-Undang tentang Badan Hukum Pendidikan dibatalkan pada tahun 2010. Namun demikian, tidak mempengaruhi materi yang didiskusikan karena esensi transparansi sudah menjadi tuntutan seluruh entitas baik profit maupun non profit di seluruh dunia.

\section{Simpulan}

Dari pembahasan di bab sebelumnya diperoleh simpulan bahwa:

- Tuntuan transparansi keuangan pendidikan tinggi semakin meningkat namun website masih berperan sebagai sarana promosi sehingga konten informasi yang ditampilkan masih berorientasi pada program studi yang ditawarkan 


\section{Pengungkapan informasi pada website...} 8 dan kemudahan layanan yang diperoleh mahasiswa. Walau demikian hampir semua perguruan tinggi telah menyajikan informasi tentang rencana stratgenya walau masih pada informasi tentang visi, misi dan tujuan.

- Belum banyak perguruan tinggi yang menyampaikan informasi keuangannya.

- Dari sepuluh perguruan tinggi terbaik di Indonesia hanya satu yang telah menyajikan laporan keuangannya.

\section{Rekomendasi}

Beberapa rekomendasi dari hasil telaah penelitian, yaitu:

- Peran Ikatan Akuntan Indonesia perlu diikutsertakan untuk mendorong pelaporan keuangan perguruan tinggi sesuai dengan standar akuntansi yang berlaku.

- Manajemen perguruan tinggi termasuk pengurus yayasan perlu merubah mindset dengan adanya tuntutan akuntabilitas public yang semakin besar.

- Manajemen perguruan tinggi juga harus cepat menyadari bahwa saat ini website bukan lagi sekedar berperan sebagai media promosi etapilebih dari itu website juga sebagai media untuk akuntabilitas publik dan transparansi.

- Bagi penelitian selanjutnya terbuka sangat lebar kesempatan penelitian terkait dengan topik akuntansi pendidikan yang belum banyak tersenutu dengan mengembangkannya ke ranah organisasi pendidikan lainnya, pendidikan menengah atau pendidikan dasar.

\section{Referensi}

Aristo, Awan Digo. 2005. "Good University Governance". http://aristodiga. blogspot.com/2005/08/good-university-governance.html

Abhiseka, A. ( 2003, January 15). E-government to be Launched to Promote Good Governance. The Jakarta Post

Bastian, Indra. 2002. Akuntansi Pendidikan. Penerbit Erlangga, Jakarta.

Gunawan, Yohanes. tanpa tahun. Prospek Badan Hukum Pendidikan sebagai Penyelenggara Pendidikan dalam Sistem Pendidikan Nasional (Kajian Politik Sistem Pendidikan Nasional, Sosial dan Budaya). Ditjen.Dikti.Depdiknas

Muttaqin, Tatang. 2009. "UU BHP dan Prospek Pengelolaan Pendidikan Tinggi". Media Indonesia. 28 September. 2009

Wahid, Fatul. 2008. "Evaluating Focus and Quality of Indonesian E-Government Websites". Seminar Nasional Aplikasi Teknologi Informasi 2008 (SNATI 2008).

http://www.ugm.ac.id

http://www.petra.ac.id

http://www.ui.ac.id

http://www.gunadarma.ac.id

http://unair.ac.id

http://www.brawijaya.ac.id

http://ww.its.ac.id

http://www.uns.ac.id

http://www.um.ac.id

http://www.itb.ac.id

http://ham.blog.ittelkom.ac.id/blog/2009/08/25/transparansi-perguruan-tinggisebuah-tantangan-baru/

http://vpf-web.harvard.edu

http://controller.berkeley.edu 


\title{
Remarrying 'the rational' to 'the myth: an investigation by using baudrillard's order of simulacra
}

\author{
Ari Kamayanti \\ STIE Mahardhika Surabaya, Jawa Timur \\ Juanda Business Centre kav B1-B7 Surabaya \\ Email: kamayanti.ari@gmail.com
}

\begin{abstract}
In the postmodern era, all things are in the process of changing from sign to simulacrum. This process is called simulation. Accounting and religions are, without exclusion, also in the process of simulation. Debates on how accounting relates to religion have been going on, probably since the claim of Weber's Ethics of Protestants and The Spirit of Capitalism. Accounting is based on rationalism, while religion that is based on intangible faith and beliefs is regarded as myth. The question is: can the two opposites be combined? This paper tries to provide other alternatives views how accounting relates to religion and how this relation also undergoes simulation. The religion views portrayed are Catholics, Protestants, Buddha and Islam. The methodology used is Baudrillard's Order of Simulacra as it contains genealogical analysis, such as that put forward by Michel Foucault. The findings, based on literature studies and empirical evidences found in religious institutions websites, confirm that there is a trend of the return of the religion in accounting: a remarrying process in this postmodern era, after it has been divorced during the enlightenment era (Auckflaruung). However, this remarrying process only happens at superficial level, exposing the fact that secularism happens in the religious institutions websites being studied, including Islam.
\end{abstract}

Keywords: Accounting, Religion, Simulacra, Simulation.

\section{Introduction}

One thing for sure, accounting nowadays is the very essence of rationality. For example, rationality is the assumption that is held in the case of Investment Theory that becomes the base of the theory of Efficient Market Hypothesis (EMH) and eventually a theory that is referred to while conducting Market Based Accounting Research. Investment theory states that it is a "...specialization of decision theory to model the decision process of a rational investor. In particular, the theory of investment helps to understand the nature of risk in a portfolio investment context" (Scott, 2009:60).

Researches also depend greatly on rationalism. Although irrationality is found in several researches such as one that was conducted by Fama and French while investigating the inability of Beta in 1992 to predict securities return or when Lev in 1989 investigated why the value relevance $\left(\mathrm{R}^{2}\right)$ is only $2-5 \%$, brought up the presence of irrational investors, rationalism is still deemed applicable to accounting as a social science. The ontological assumption made by Watts and Zimmerman (1986: 4) while devising accounting theory is clear. They viewed that reality is 'relation between variables'. Therefore, referring to this state of accounting, it is quite agreeable to name accounting as 'the rational'.

On the other hand, religion is about faith and belief. In this area, rationality is regarded out of the picture. One could not rationalize sense of being close to God. Even God is intangible. All those that are intangibles could not be observed or measured. Religion is 'the myth'. Beller (2001) describes that the scientific

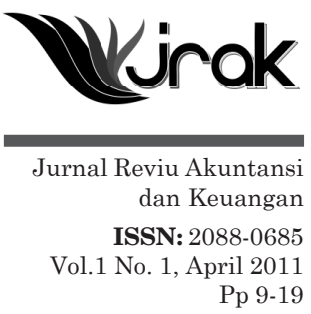




\section{Remarrying 'the rational' to 'the myth': an}

worldview has been synonymous with the claim that there is no God while the religious worldview has been equated with the claim that God is not of this world. This logically should create a conflict.

Whether we like it or not, we are now living in the world of simulacra. A term introduced by Baudrillard to refer to the signs, images, models or pretences that has no resemblance to any reality. This is a character of postmodernism era. It is not an overwhelming statement that accounting and religion today, as stated by McKernan and Kosmala (2007), now operate in environment that is effectively postmodern. To reach a simulacrum there is a simulation. This is a process of where a sign is being transformed towards pure simulacrum. Both accounting and religion, so it seems, undergo this process.

Accounting as eloquently described by Macintosh et al (2000), has changed over time. During the ancient Sumerians in the year of 3500 BC, accounting depicted reality without ambiguity, as urns and tokens were used to account for any transaction involving physical realities. By the time of the middle Ages, accounting was used to control the activities of properties lending by landowners. Then as the Italian merchants started to have passive partners, accounting begun to take its role as a stewardship means. All things evolve and accounting nowadays is not as transparent as it hopes to reflect. With various techniques and regulations, all things equal, a company could choose to report its income differently. This is simulacrum: the sign (income statement) has preceded reality. Worse still, this hyperreality has become the base of decision making such as we see in many market based accounting researches. Macintosh et al. (2000) differ simulacrum from hyperreality. "...simulacrum is a sign, image, model, pretence, or shadowy likeness of something else. Hyperreality refers to the current condition of postmodernity where simulacra are no longer associated with any real referent where signs, images, and models circulate, detached from any real material objects or romantic ideals"

If accounting goes through simulation then what about religion? The Quran as claimed does not change. The bible certainly has different versions; there are The Old and The New testaments. However, if we emphasize on the practice of these religions and how they diffuse through life and social practice, it could be seen that there are significant changes. The role of Islamic women, for instance, who once served no more than their own households, now are actively and largely involved in social, economic and even political matters. Hermeneutics, particularly allegoric interpretations of holy texts, could be awarded for the simulation of religions. The trend that holds the view that all religions are equals, such as the spirit carried by Anand Krishna, is a simulation. The practice of ESQ (Emotional Spiritual Quotient) by Ary Ginandjar is also simulation- that a tranquility, an inner peace, every spiritual experience could be created, mass consumed and bought. The labels of 'Halal' and 'Syariah', that are used to envisage the unreal facts beneath them, are also simulacra.

The two seems to be related. There is this work by Weber claiming that it is the protestant ethic that brings the spirit of capitalism, and that accounting has been articulated to give rise to capitalism through rationalizing economic action (Christie et al. 2004). Sombart argues that it was the Jews who were best able to use modern accounting to accumulate wealth. Sombart's thesis depicts that accounting has a "Jewish spirit" (Funnel, 2005). There is also the rising local interest in syariah accounting such as the recent accounting concepts and techniques put forward by Triyuwono (2006) and Mulawarman (2009), as well as similar international interest such as the establishment of Accounting and Auditing Organisation for Islamic Financial Institution (AAO-IFI) in 1991.

This paper tries to explore the relation of religion and accounting and how this relationship, if any, evolves from the ancient times to the era of postmodernism where simulacra prevail. Thus the proposed research questions are: How is accounting related with religions through change of time? And how do accounting signs move towards simulacra in each religious perspective? 
Which one precedes the other? Is it religion or is it accounting? Do religions form accounting practices? Or do accounting practices evolve without any religion, and religions assume their dignity hence claim that accounting practices are derived from them? To answer these questions as well as to describe how signs changes to simulacra, a methodology deemed proper is Baudrillard's order of simulacra. It explains how sign moves from a reflection of profound reality to simulacrum in four phases:

"In the first phase, the sign is a reflection of a profound reality... It is a good appearance in the sense that it is a faithful and transparent representation... In the second phase, the sign masks and departures a profound reality. It is a bad appearance distorted or twisted image, which deprives reality of its deep-seated quality. In the third phase, the sign masks the absence of any profound reality. Akin to magic, it plays at being an appearance of a reality. Finally, in the fourth phase, the relationship is reversed: the sign precedes reality; it has neither rapport with nor resemblance to any reality; it is pure simulacrum" (Macintosh et al., 2000)

Baudrillard also uses genealogy such as put forward by Foucault. Mahon in Macintosh et al. (2000) explains that genealogy is "a unique form of critique which recognizes that the things, values, and events of our present experience have been constituted historically, discursively, and practically...it reveals the historical, discursive and practical conditions of existence of these things, values, and events". This is similar to Foucault's genealogy, which is a method in which the objective is to distinguish and describes ruptures and transitions in history and idea (Baker, 2004). Genealogical analysis is concerned with knowledge and power to demonstrate that history is not linear. The two processes comprise discontinuity and contingencies.

This paper proceeds as follows. After the description of methodology, the evidence of the presence of religions and accounting practices as well as their relations are investigated through several literatures and empirical studies. This would provide a general assumption on accounting practices in various religions.

Next, I shall explore these relations but in specific religions. My focus is in Catholics, Protestants, Buddha and Islam. It does not mean that accounting does not exist in any other religion, but at the moment these are the religions that provide sufficient literature and empirical studies for this research. For every religion under investigation, historical events (ruptures) or empirical studies concerning the religions and accounting are discussed. Also under each religion, the order of simulacra (how accounting and religions alter) are also brought to light. Since, we are now embarking a virtual world, evidences on accounting practices in religions are gathered from several websites of religious institutions.

\section{Investigating Historical Ruptures: The Divorce of 'The Rational' from 'The Myth}

Accounting is derived from religion. This statement stems from the following explanations. If accounting is also referred to double-entries bookkeeping then some religions debate on the claim of the accounting establishment. Aho in Derks (2008) explains that medieval pope (Roman Catholic) invented double-entries bookkeeping. In contrast, Weber has stated the reliance of accounting on Calvainism or Judaism (Protestant). Sombart argued that bookkeeping was used successfully by Jews to transform the economic and social relations to the point where they could sustain modern capitalism (Funnell and Williams, 2005: 358). Luca Pacioli was a monk that wrote the first known manual of double-entries bookkeeping, though he wrote it in a small part of a book about mathematics some 150 years or so after double-entries practices are known to have surfaced in several north Italian cities. Derks (2008) even reports finding that there is possibility that the West 


\section{Remarrying 'the rational' to 'the myth': an}

12 learned double-entries bookkeeping from the early Arabs (Islam). So far it could be concluded that accounting is originated from religions. Accounting is tightly related to the religions, but this condition does not prevail long.

As people grew restless during the era of enlightenment, as the church was losing its power, secularism took place. There are reasons why this 'divorce' between accounting and religion has taken place. Kamla (2009) states reasons as to why religions are regarded as some 'junks' that must be thrown away- divorced from science. The separation of God from knowledge is a trait of secularism. Al Attas (1981) describes this as secularism; disenchantment of nature. Kamla (2009) further delineates that religions are utilized to achieve goals and maximize wealth, and protect the religious elite from public scrutiny. Religions are mere masks. Furthermore, she sees religion, mainly Islam, fosters fundamentalism and public repression thus threats modernity and enlightenment.

The nature of religion itself has strengthened the simplistic understanding of binary opposition. Sugiharto (2008: 185) describes that religions put a distinction between paradise-hell, sins-good deeds, and halal-haram. Religions have maintained fears and blind surrender. Therefore, there is urgent need to liberate human beings from this transcendent cage and to give space for their autonomies. This liberation puts religion into cultural alienation.

Hermeneutics play a part in this divorce as allegorical interpretations towards text deny the literal interpretations and are further supported by science findings. The bible (Revelation 7: 1) states the presence of four angels standing at the four corners of the earth has given literalists idea that the earth is not round. Thus the church condemned Galileo Galilei to death when he exposed heliocentric law, which states that the sun is the center of the universe, not earth as so profoundly claimed by the literalists (Husaini, 2004). However, as science supported evidences that rejected literalist interpretations towards the bible, the magisterium power of the church tumbled. Hence, comes the era of enlightenment, modernity, auckflaruung. The modernity project is concerned on liberating rational thoughts from myths and religions irrationality (Zarkasyi, 2004).

After that, religions find their ways in the process of simulation. Karl Marx believed that religion is just an addiction, an imaginary world; a sanctuary that human seeks protection from the harsh reality. Religion is a form of human protest to the oppression and disgust of the real world. The modernity extends further to claim, through Friedrich Nietszhe, the 'death of God'. Religion is a realm created by those who are losing in life, fearing the authorities, and hope to gain victory in the after-life (Sugiharto, 2008: 189)

The simulation reaches further still. It was people like Fritjof Capra who finds the missing link between science and the transcendent world. In his book The Turning Point, he describes that modern science has thrived to exist in imbalances for it puts too much emphasis on mechanistic world; rationality. Rationality, according to Capra (2007: 25) is one of the characteristics of masculinity or Yang. Suddenly there is a surge of need to seek back transcendental and sacred values since modernity does not seem able to solve human problems.

However, there is now a change in the religion in this era; an era of postmodernism. The religion is not viewed from fundamental perspectives but tends to be viewed from spiritualistic perspective. This spiritualistic approach according to Griffin (2005: 116) is an evolution of religion: from theistic before the modernism, anti-theistic in modernism and finally naturalistic theism in postmodernism. In this view God is not supernatural; God is part of the natural order. God is a part of the cause-effect temporal sequence, and God's activity is nothing but natural. God is, quite simply, one of individual entities that acts and reacts, influences and persuades, and is part of the process of becoming and changing. Beller (2001) describes this God as follows:

"God is part of the process of the universe expanding, life developing, and the earth spinning around and around. God does not control this process; God 
acts through persuasion, rather than coercion, and has to compete with the virtually unending number of forces contained in the cause-effect temporal sequence. On the basis of this, I would submit that theistic naturalism makes

belief in God more intellectually satisfying."

The "return of the religions", a phrase mentioned by Derrida (McKernan and Kosmala, 2007) is also occurring in accounting at this postmodern era. For example, accountants are experiencing a sense of responsibility to be fair and just beings. There is a growth in Corporate Social Responsibility, environmental accounting in management accounting, and even socio-spiritual accounting.

\section{Order of Simulacra: Accounting Through the Spectacles of Religions}

In this section I would explicate each religious perspective in term of accounting practices and how they evolve through time based on literature studies. Next, using available evidences on religious institution websites, the presence of accounting is explored.

\section{The Spectacles of Catholics}

In this section I do not distinguish the Catholics from The Hebrew Catholics. This might be over-simplistic, I must admit, but since they originate from the same roots, I thought it would be best to keep them under the same section. The earliest evidence of accounting is the concept of wealth found in the code of Hammurabi concerning property, lending of money and house renting that reflects the presence of accounting practice. The Hammurabi was thought to be originally engraved in the $18^{\text {th }}$ century BCE. The Hebrew Bible describes how Abraham gained his wealth from the encounter with the Pharaoh (Baker, 2004).

Gellis et al. (2002) also discovers the relation between the Torah (Hebrew Bible) and accounting. He delineates that the prophet Joseph was a great accountant for he managed to bring Egypt through the drought for seven years. The prophet Moses was considered an auditor and acknowledged the use of an independent auditor, for he has done such activities while counting the contributions made by the Israeli.

At this stage, accounting represented the reality. The Code of Hammurabi explains the rules over accounting practices in order to record transactions and to provide evidence about trading and lending activities. For an instance, one aspect of the code "specified that an agent selling goods on behalf of a merchant must provide the merchant with a written price quotation, or face the possibility of having a disputed agreement invalidated" (Baker, 2004). Accounting was used only to account for activities, a tool of stewardship.

Simulation of this stewardship seems to occur during $16^{\text {th }}$ and $17^{\text {th }}$ centuries in the accountability of practices in the Society of Jesus. By this time "...development of accounting practices can not be reduced to an economic explanation that views them merely as tools for measuring and allocating...rather, their development and refinement were tightly linked to the absolutist ideology of the Roman Catholic Doctrine..., conceived of here as a complex work of compromise among theological, religious, political, institutional and societal instances..." (Quattrone, 2006). The accounting sign has moved to the next order of simulacra, as it reflects not just real numbers but a consensus of various interests.

Jacobs (2005) has investigated the acceptance of accounting in the Church of England (Anglo-Saxon) - a Catholic church. He discovers that some clerks and members of the church view accounting as secular. Accounting is antithetical to religious values that are contrary to sacred values and orientation of religious organizations. At this stage it can be said that the 'divorce' of accounting and catholic religious values is apparent. However, the fact accounting is still used in practice shows that it is not completely rejected amongst the congregations. Jacobs (2005) finally concludes that: 


\section{Remarrying 'the rational' to 'the myth': an}

“...what is sacred or secular can change with different individuals and different settings and the narratives recounted suggests that the problem might be a jurisdictional conflict between accountants and clergy rather than a clash between the values the Church and the secular values embodied in accounting practice."

A website on Catholics religious institution named The Catholics Church in Australia at http://www.catholic.org.au, does not include accounting practice (acceptance and accountability of donation). However, what is interesting is the confirmation in documents section that since the activities conducted by the church is not-for-profit, it should be protected by law:

"The point can be summed up using an analogy from the business sector: our society's deposits or stock of social capital have been built up over centuries by the ethical attitudes given expression in word and deed by our charitable institutions, especially our religious institutions, while our political and economic institutions make withdrawals on that social capital, using it to further develop and refine our laws and our economy. But our social capital resources, like our natural resources, cannot be taken for granted. Once depleted, they are not easily restored. They are fragile and must be carefully nurtured and afforded the protection of the law."

Implosion of values, in this case the emergence of political and economical issues in accounting for religion, has suggested that accounting practice in this website has focused on the going concern of the institution instead of simple profound stewardship to its donators. Notice the use of economic terns such as "business", "capital", and "economy". Accounting has been used to accumulate wealth (means that it should be protected by law), which proves Sombart's thesis (Funnel, 2001). There is hope in the future for God in accounting as the divisions between the sacred and the secular has become vague. It might be that the sign (read: accounting) is finally turning to simulacrum, when it is employed as a tool to protect religious institutions existence and wealth accumulation.

\section{The Spectacles of Protestants}

Perhaps the most interesting religion that can be related to accounting is the Protestants. Ever since the work of Weber's Ethics of Protestants and the Spirit of Capitalism, through Calvinism, the Protestants claim that: "material wealth was a sign of a person's eventual salvation" (Christie et al., 2004). Double-entry bookkeeping is utilized to achieve this salvation, although it must be noted that there is a debate on this since Roman Catholicism also claims to be the pivotal role of double-entry bookkeeping (Derks, 2008).

Weber regards individualism as a defining characteristic of the protestant ethic moral point of view that differ Protestants from Catholics. When Adam Smith in 1976 wrote Wealth of Nations, this individualism is further legitimized and reaches a virtue of the highest order. Hence, it is the birth of capitalism.

It is capitalism that stimulates the simulation. As described earlier, accounting signs becomes simulacra as wealth accumulation becomes the focus of every transaction. As the Italian merchants introduced nominal accounts, accounting does not represent only physical reality but also social reality (Macintosh, 2000). Capitalism has thrived on the concept of efficiency and rationalism, divorcing further the myths from the rational.

Christian religious institutions whose websites were under investigation in this article were Gereja Patekosta Tabernakel Kristus Kasih (GPTKK). It owns a website with a page address http://www.gptkk.org/lain.php. In this website, there is no information of how one could donate to the charity or any accountability information. It seems that the page only focuses on religious services (home, testimony, revelation, revelation transcripts, history and church's profile). However, 
another page of Christian institution called City Life Church at http://www. citylifechurch.com describes the need of financial support and the use of donation in funding religious activities, though not in great length or details. It describes:

"As a church, we have seen hundreds of thousands of dollars invested each year in spreading the gospel to other nations as we partner together, each giving what God has prompted us to give. Financial support for our World Impact ministry comes from:

Tithe of the Tithe. 10 percent of the church's tithe is used to finance external ministries. The missions portion of the tithe of the tithe provides a base level of support for CityLife missions workers (generally around $35 \%$ of their total yearly budget). It also covers pastoral care of missions workers and the administrative costs of the ministry.

World Impact Partnership Giving. Congregation members are encouraged to make planned faith commitments to support the missions vision of the church at our annual World Impact Week. These World Impact Partnership commitments are used to fund priority projects and needs including support of national workers, training of national leaders, outreach teams and ministry projects for CityLife missions workers"

There is a sense of faith and truthfulness conveyed. Although explanations are given on how fund is collected, there is no detailed report of how the raised fund is spent. There is no report whatsoever of the amount collected or spent or its exact allocation. At this website, the presence of accounting is confirmed only as stewardship to God: "dollars invested [to do] what God has prompted". This gives 'justification' of the negligence of detailed financial reports. Accounting is portrayed only as a budgetary instead of accountability tool.

\section{The Spectacles of Buddha}

Liyanarachchi (2009) discovers that there are evidences of accounting and auditing practices that prevailed in ancient Sri Lanka (from 815 to 1017 AD) and discusses motives for using such practices by a religious institution. He employs methods of data collection through detailed translations of rock inscriptions, which have been carried out by various personnel. The evidences show that the Buddhist monasteries were required to keep accounting records and these records are annually read aloud to the public.

Accounting in the Buddhist monastery was relied upon to maintain the reputation of a monastery and that of its members, and to maintain goodwill among Buddhist monks, rulers, and people. The prevalence of accounting and auditing practices in ancient Sri Lanka adds further support to the theory that the origin of record keeping and accounting practices dates back to ancient times.

The fact that the records were read aloud shows that accounting was used mainly as a stewardship tool to account for the amount of wealth received and used by the monastery. At this stage it was most probable that accounting still explains the physical reality.

I did find a case of a Buddhist Monastery that is promoting its teachings through the internet. This is Cittaviveka Monastery. According to the website, this monastery:

“...does not receive support from any powerful backers or institutions; it sells nothing and all teachings as well as books are given freely. No charge is made for people to stay here; the resident Sangha is prohibited from possessing or dealing in money. The community draws from its own skills to keep the monastery going, and in this is aided by various lay advisory committees. The Cittaviveka Advisory Group and the English Sangha Trust supervise these. Cittaviveka is completely dependent on donations. It is financially managed 


\section{Remarrying 'the rational' to 'the myth': an}

by the English Sangha Trust, a registered charity which can receive and administer any such donations" (http://www.cittaviveka.org, downloaded $3^{\text {rd }}$ June 2010)

If the donation is financially managed then there is more than a good chance that accounting is still used as stewardship tool. Of course, the practice of "reading aloud" donation is no more apparent in this website, which shows that the term "accountability" has evolved. Donation, as found in previous web in the Protestant religious institution is not limited to money only. The website further delineates that several ways to support Cittaviveka;

"By offering money - to the monastery steward or lay Treasurer. By offering requisites - such as food, furnishings, equipment. By offering service - in terms of skills or advice. By sponsoring books - Our teachings appear in books for free distribution only when there are free-will donations of money to cover the costs and offers to help with typesetting and design etc. If you'd like to help please look at http://forestsangha.org/projects.htm and contact the relevant monastery or The Publications Secretary at Amaravati: abmpublications[at]googlemail.com."

However, like the many religious websites found, this website does not give detailed accounts of the amount of fund collected and distributed. Therefore, accounting practice in the Buddhist Monastery nowadays, referring to Cittaviveka, seems to be similar to several religious websites in this study.

\section{The Spectacles of Islam}

"O you who believe! When you deal with each other, in transactions involving future obligations in a fixed period of time, reduce them to writing let a scribe write down faithfully as between the parties; let not the scribe refuse to write; as Allah has taught him, so let him write. Let him who incurs the liability dictate, but let him fear his Lord Allah..." (QS Al Baqarah (2:282)"

The Quran has depicted accounting practice and set a rule of what must be written for certain transactions. So in this case there is no doubt that accounting is related to religions. Baker (2004) also discovers that the description of Abraham's wealth in Genesis is congruent with the view of wealth in Islamic view. He concludes within genealogical analysis about Abraham's accounting practice, "..while there is no specific evidence that Abraham accounted for wealth using clay tablets... or papyri like in Egypt...it would not be unreasonable to suggest that Abraham used some form of accounting practice to record his wealth".

The debit-credit in accounting that was practiced during the khalifah Umar bin Khatab in 12-42 Hijriyah (636-645 AC) until the Abasiyah era 132-232 Hijriyah (750- 847 AC) (Syafi'i in Triyuwono 2006), were absorbed by the West. Hamid in Adnan (2002) has researched and found that accounting practice (double-entry bookkeeping) did not originate from Italy but has been implemented by the Islamic government eversince the $10^{\text {th }}$ century.

As capitalism prevails during the enlightenment, these methods serve its purpose to support capitalism, hence the divorce of religion from accounting is transpired. Only during the last two decades, according Adnan (2002: vi) that Islamic accounting or Syariah accounting has started rising. This is the return of the religion- remarrying accounting to religion.

In Indonesia alone, with the Syariah Banking Regulation no. 21 2008, its asset has grown to $65 \%$ per year in the last five years (http://www.bi.go.id). Throughout the world, the Islamic banks continue to rise. The estimated number of Islamic banks around the world has reached 396 throughout 53 countries and the estimated volume of funds within the Islamic banking sector stands at US $\$ 442$ billion, according to a report by the General Council for Islamic Banks and Financial Institutions [GCIBFI] in 2008 (http://knol.google.com/k/lahem-al-nasser/islamicbanking-in־numbers). 
There is a simulacrum pertaining to this phenomenon. Several findings by Kuran, Patel, Newton in Kamla (2009) suggest that: "the only difference between conventional and Islamic banking is in its appearance: Islamic banks are managed by religious council, their headquarters are full of signs of Islamic piety, veiled females and bearded males". International Organization for Islamic Banks also found that less than $20 \%$ of Islamic banking operations adopt PLS techniques. Could it be that all this religion labels are merely image of religions but not the real religion? If this is so, then it is time to say: "welcome to the world of simulacra".

However, in term of fund raising through zakat, infaq and sadaqah (ZIS) in the internet, there are websites that have given reports on their distribution. One of which is http://www.e-zakat.com.my. Resembling a CSR report, it gives explanation of spending with images/pictures to account for ZIS distribution. A website found by The Islamic Society of Holland Park Mosque at http:// www.hpmosque.org.au provides link to "donation" for the mosque. It asks the followers to contribute:

"What the public do not realise is that since its formation in 1908, Holland Park Mosque has only ever relied on the community for any financial contribution for the maintenance of the Mosque - that is our only source of funding!

As you can appreciate, the running costs of the Mosque are very high when you take into consideration the various activities carried out by this Mosque. It is the known centre of Islamic activity in Queensland with regular programs, Islamic classes, lectures from our learned Imam, Maddressah and Quran Hifz classes conducted by Qari Mehboob Ul Haq, it is definitely the hub of Islamic activity.

Unfortunately, all this comes at a costly financial price when you take into consideration the salaries of both the Imam and the Qari (they have to earn a living and support their families), the cost of running the Maddressah, costs of preparing Islamic classes, the day to day administrative and running costs, Maintenance and repairs, ongoing renovations and building including periodical extensions to the Mosque and the many other Islamic organisations that rely on our financial and moral support to help motivate them in establishing their own Islamic presence.

We do not receive funding from any organisation, government or otherwise. Our only source of income is acquired from the generosity of the local community and from fundraising activities. However, due to the growing running costs and the emergence of other Mosques and Islamic Centres the income is getting very scarce."

It is interesting to note that the economic terms have entered the texts. These are "cost", "financial", "scarce" and "price". The bold words have confirmed how tangible assets are imperative for "Islamic Presence". It is also interesting to note that the mosque is using these terms to maintain its existence amongst the "emergence of other mosques and Islamic Centres". Even religious institutions are in competitive atmosphere against each other, and accounting terms are weapons in the competition. The transcendence has materialized to the physical through the support of economic view. The page does not contain further detailed quantitative amounts received or spent. Again, the sense of accounting as fair and trustworthy practice is conveyed, or at least there is an assumption that religious institution is sure to be honest about donation spending. An assumption that neglects the need of detailed accountability for charity requires sincerity; and sincerity cancels out responsibility. Accounting has evolved from simple stewardship into competitive tools. 


\section{Remarrying 'the rational' to 'the myth': an}

\section{Temporal Conclusion}

If Derks (2008) concludes that there is no historical basis nowadays for understanding the relationship between Western religion, capitalism and doubleentry bookkeeping, then I conclude that there is to a certain degree a relation between religion and accounting. This relation is not always constant. There were times during the age of modernity, or Auckflaruung, the rational accounting is 'divorced' from the myth: the religion. However, like a circle of life, as modernity lacks resources to solve most of human problems, there is a "return of the religion". Though not in a similar form, this religion is trying to balance the rational and the myth, an implosion takes place. Through this process of "marriage-divorce-remarriage", a simulation also occurs. Accounting signs are turning into accounting simulacra and apparently this phenomenon happens in almost every religion, according to empirical findings shown in the investigated websites.

There is limitation to this research. It would have improved if efforts were further given to find reasons behind the presence and absence or limitation of accounting (in this case financial reports comprise collection and allocation of fund) through deep interviews to the religious institutions. Greater coverage of data might elucidate different findings. Further research on these notes could become the next agenda.

This circle of life will not be coming to an end, if any return to the religion is a sheer profane spiritual. There will be a continued process of marrying and divorcing but not eternally ever lasting. Unfortunately, In Islamic religious institutions as portrayed in the investigated websites, similar trend does occur. Syariah accounting that exists in syariah banks is a result of pragmatic approach that does not touch thoroughly the philosophical foundations. That is why there are phenomena observed by Kamla (2009) that these religious traits become mere labels, instead of making religious values as the bedrocks of knowledge practices. There is a need to get down to ontological and epistemological discourses to integrate values into practices. To break down the world of simulacra, we need to understand that both profane spiritual religion view as well as accounting practices have evolved to be what they are not. This is what must be done, unless we are happy enough living in the world of simulacra, or are we? Wallahu'alam bishawab.

\section{Reference:}

Adnan, Achyar. 2002. Akuntansi Syariah; Arah Prospek dan Tantangannya. Yogyakarta: UII Press.

Al Attas, Syed Muhammad Al Naquib. 1981. Islam dan Sekularisme. Translated. Bandung: Penerbit Pustaka.

Baker, C. Richard. 2004. Accounting in The Bosom of Abraham: A genealogical Investigation of Wealth. Fourth Asia Pacific Interdisiplinary Research in Accounting Conference. Singapore, 4-6 July. p 1-18.

Beller, John. 2001. God in Our World: Engaging David Ray Griffin's Religion and Scientific Naturalism. Drury University. http://www.drury.edu.

Capra, Fritjof. 2007. The Turning Point: Titik Balik Peradaban, Sains, Masyarakat dan Kebangkitan Kebudayaan. Yogyakarta: Penerbit Jejak.

Christie, Nancy, Bruno Dyck, Janet Morrill and Ross Stewart. 2004. Escaping The Materialistic- Individualistic Iron Cage: A Weberian Agenda for Alternative Radical Accounting. Fourth Asia Pacific Interdisciplinary Research in Accounting Conferences. 4-6 July.

Derks, Hans. 2008. Religion, Capitalism and The Rise of Double-entry Bookkeeping. Accounting, Business \& Financial History. Vol 18., No. 2, pp 187- 213.

Funnell, Warwick and Roberts Williams (ed). 2005. Critical and Historical Studies in Accounting. Australis: Pearson Education Australia. 
Funnell, Warwick. 2001. Distortions of History, Accounting and The Paradox of Werner Sombart. Abacus. 37 (1), p 55-78.

Gellis, Harold, Kreindy Giladi, Hershey H. Friedman. 2002. Biblical and Talmudic Basis of Accounting Ethics. The CPA Journal, Sept pp 11-13.

Griffin, David Ray. 2005. Tuhan dan Agama Dalam Dunia Postmodernisme. Yogyakarta: Penerbit Kanisius.

Husaini, Adian. 2004. Problem Teks Bibel dan Hermeneutika. Islamia: Majalah Pemikiran dan Peradaban Islam. Tahun 1 No 1 Muharam.

Jacobs, Kerry. 2005. The Sacred and the Secular: Examining The role of Accounting in the Religious Context. Accounting, Auditing and Accountability Journal. Vol 18 No 2. pp 189- 210.

Kamla, Rania. 2009. Critical Insights into Contemporary Islamic Accounting. Critical Perspective of Accounting. xxx. Pp 5-16.

Liyanarachchi, Gregory A. 2009. Accounting in ancient Sri Lanka: some evidence of the accounting and auditing practices of Buddhist monasteries during 8151017 AD. Accounting History. Vol. 14, No. 1-2, pp 101-120

Macintosh, Norman B, Teri Shearer, Daniel B. Thornton and Michael Welker. 2000. Accounting as Simulacrum and Hyperreality: Perspectives on Income and Capital. Accounting, Organisation and Society. 25, pp 13-50.

McKernan, John Francis and Katarzyna Kosmala. 2007. Doing the truth: religiondeconstruction- justice and accounting. Accounting, Auditing and Accountability Journal. Vol 20 No. 5, pp 729-764.

Mulawarman, Aji Dedi. 2006. Akuntansi Syariah: Teori, Konsep dan Laporan Keuangan. Jakarta: E-Publishing Company.

Quattrone, Paolo. 2006. Accounting for God: Accounting and Accountability Practices in The Society of Jesus (Italy, XVI- XVII Centuries). Accounting, Organisations and Society. Vol 28. pp 169-249.

Triyuwono, Iwan. 2006. Perspektif, Metodologi, dan Teori Akuntansi Syariah. Jakarta: PT. Grafindo Persada.

Scott, William R. 2009. Financial Accounting Theory. Fifth Edition. Toronto: Prentice Hall.

Sugiharto, Bambang. 2008. Humanisme dan Humaniora: Relevansinya bagi Pendidikan.

Watts, Ross L and Jerold L. Zimmerman. 1986. Positive Accounting Theory. New Jersey: Prentice Hall.

Zarkasyi, Hamid Fahmi. 2004. Menguak Nilai di balik Hermeneutika. Islamia: Majalah Pemikiran dan Peradaban Islam. Tahun 1 No 1 Muharam 1425/ Maret 2004.

\section{Websites:}

http://en.wikipedia.org. Downloaded $1^{\text {st }}$ June 2010.

$\mathrm{http}: / / \mathrm{knol}$.google.com/k/lahem-al-nasser/islamic-banking-in-numbers. Downloaded 20th May 2010.

http://www.bi.go.id. Downloaded $1^{\text {st }}$ June 2010.

http://www.catholic.org.au. Downloaded $3^{\text {rd }}$ June 2010.

http://www.citylifechurch.com. Downloaded $3^{\text {rd }}$ June 2010.

http://www.cittaviveka.org. Downloaded $3^{\text {rd }}$ June 2010.

http://www.gptkk.org. Downloaded $5^{\text {th }}$ June 2010.

http://www.hpmosque.org.au. Downloaded $5^{\text {th }}$ June 2010.

http://www.e-zakat.com.my. Downloaded $5^{\text {th }}$ June 2010. 
